\title{
MAKNA DIBALIK TRADISI NIKI PALEG SUKU DANI DI PAPUA
}

\author{
${ }^{1}$ Bagaskoro Bisono Putro, ${ }^{2}$ Ananda Salsabila Nadira \\ 1,2 Progran Studi Ilmu Komunikasi Universitas Pembangunan Nasional "Veteran" \\ Jakarta, email : bagaskbp@gmail.com., email : ansabilna23@ gmail.com
}

\begin{abstract}
This paper aims to find out the meaning behind the Dani Niki Paleg Tradition from Papua. This study was made using a type of literature study, which is done by finding references to relevant theories with the topics to be discussed. For Dani, togetherness is a matter That is very important. Then from there if there are some of those who lose their family members, the Dani tribe has a tradition called Iki Paleg. Where they will cut a portion of the finger segment as a symbol to represent the feeling of loss. what meaning is contained in every tradition of Iki Paleg that is carried out.
\end{abstract}

Keywords: tradition,Dani Tribes, symbol,mean.

\section{PENDAhUluan}

Sebagai negara yang terkenal dengan kemajemukannya atas keragaman suku bangsa, budaya, agama serta adat istiadat, membuat Indonesia kaya sekali akan kebudayaan nasional. Tak terlebih dengan berbagai macam suku bangsa yang diketahui memiliki ciri khasnya masingmasing. Kebudayaan yang mereka miliki merupakan kebudayaan yang sudah ada dari generasi ke generasi. Kebudayaan tersebut akan tetap ada secara turun temurun dan berlangsung secara terus menerus. Hal tersebut mencakup hasil dari karya cipta, rasa dan karsa manusia mengenai aspek kehidupan seperti hukum, keyakinan, seni, kebiasaan, moral dan yang lainnya.

Papua sebagai salah satu pulau dengan wilayah terluas di Indonesia, terdiri atas bermacam-macam suku yang masih memegang erat adat istiadat maupun tradisinya tanpa ada pengaruh dari budaya asing. Sebut saja suku Asmat, suku Biak, suku Sentani dan juga suku Dani yang merupakan penduduk asli pulau Papua.

Berbicara mengenai kebudayaan suku-suku di Papua, suku Dani yang mendiami wilayah Pegunungan Tengah, Papua memiliki sebuah tradisi yang dapat dinilai sebagai tradisi ekstrim yang cukup mengerikan. Untuk menggambarkan perasaanya atas rasa kehilangan dan duka akibat ditinggal orang-orang terkasih, suku Dani melambangkan rasa sedihnya bukan hanya dengan menitihkan airmata melainkan juga dengan memotong jari-jari mereka. Hal tersebut wajib dilakukan jika terdapat anggota keluarga atau kerabat dekat seperti ayah, ibu, adik dan kakak yang 
meninggal. Suku Dani mengartikan tradisi memotong jari tersebut sebagai sebuah simbol dari pedihnya hati ketika ditinggal seseorang yang dikasihi. Namun, tak jarang pula tradisi tersebut dianggap sebagai pencegah dari adanya malapetaka yang merenggut nyawa anggota keluarga yang meninggal.

Kematian merupakan realita yang tidak dapat dihindari dalam kehidupan umat manusia. Setiap individu pun memiliki cara yang berbeda-beda untuk menangani masa dukanya, bahkan tak hanya individu sekelompok masyarakat pun mempunyai upaya tidak sama dalam menangani pengalaman dukacitanya. Disebutkan bahwa dukacita bermakna kesedihan yang mendalam disebabkan karena kehilangan seseorang yang dicintainya (misalnya kematian). Mengutip dari Wiryasaputra (2003) bahwa "pengalaman kedukaan bersifat universal, tanpa membedakan pekerjaan kedudukan suku bangsa, warna kulit, asal-usul, agama dan tempat tinggal", bahwa tak ada satu orang pun di bumi ini sanggup menyisihkan atau menaklukan rasa duka yang hadir apalagi mengabaikannya, sebab peristiwa dukacita tersebut mempengaruhi pikiran, perasaan, dan perilaku manusia.

Dalam suatu kalangan masyarakat tertentu, terdapat tradisi yang sangat berpengaruh, dimana aturan-aturan tersebut sudah diwariskan dari satu generasi ke generasi berikutnya tanpa mengalami suatu perubahan yang mana cenderung monoton. Karena kematian adalah bagian terbesar dari kehidupan manusia, maka setiap kebudayaan pasti memiliki kebijakan dalam mendukung warganya melewati masa dukacita. Dimana pastilah setiap suku dengan kebudayannya masing-masing memiliki perspektif yang berbeda mengenai konsep sebuah kematian.

Mengartikan sebuah kematian adalah bagaikan separuh hidup mereka yang direnggut secara paksa. Yang mana tentunya berdampak pada duka mendalam atas kehilangan tersebut, suku Dani mengungkapkan perasaannya itu dalam perbuatannya memotong jari-mari mereka. Orang-orang suku Dani menjalani tradisi tersebut secara sadar hingga membuat hal tersebut sebagai simbol atas dukacita sekaligus penghargaan terhadap orangorang tercinta dalam keluarga yang telah meninggal.

Hubungan kekeluargaan merupakan bagian utama bagi masyarakat suku Dani, sebab merupakan susunan dasar yang dianggap penting dalam sistem masyarakatnya. Segi kekeluargaan dalam hal itu mencakup budaya pemotongan jarijari anggota keluarga yang masih hidup, 
karena dinilai bagaikan simbol kerukunan, persatuan, dan kekuatan dalam sebuah keluarga. Alasan mengapa jari dipilih sebagai simbol dukacita oleh suku Dani karena mereka menyebutkan walaupun jari di tangan manusia hanya terdapat ibu jari selaku representasi keluarga. Meskipun begitu, ukuran bentuk dan panjang setiap jari yang tidak sama tetap merupakan sebuah satu kesatuan yang saling memenuhi sebagai kesepadanan dalam hidup. Maka kalau satu bagian pergi, lenyaplah unsur kebersamaan dan kekuatan.

Selain itu, terdapat alasan lain mengenai kaidah dasar menjalin kehidupan sebagai satu keluarga, satu suku, satu asal dan sebagainya. Perihnya luka dan tetesan darah yang tertinggal menjadi lambang suasana dukacita seseorang yang ditinggal oleh anggota keluarganya. Barulah ketika luka-luka potongan pada jari-jari tersebut sembuh dan tak terasa lagi, maka masa berduka pun dianggap telah berakhir.

Orang-orang suku Dani tak dapat mengambil tindakan apa-apa atas tradisi pemotongan jari yang biasa disebut dengan Niki Paleg ini karena sudah merupakan adat istiadat yang melekat di tanah Papua. Mereka pun sudah menganggap budaya ini sebagai sebuah kewajiban sehingga mereka akan melakukannya secara sukarela.
Walaupun, di lain sisi orang-orang suku Dani mengaku tak dapat berbuat banyak dengan jari-jari mereka yang tidak utuh. Secara sederhana, arti keluarga bagi suku Dani dapat dianalogikan seperti lima jemari dengan satu kegunaan gerak yang sama.

Biasanya, seorang suku Dani yang sudah menuntaskan kewajibannya menjalani tradisi Niki Paleg akan menyandang rasa bangga dan lebih diterima di lingkungan sekitarnya sebab telah melunasi keharusan adat istiadat yang dimiliki sebagai simbol pilu atas kepergian orang terkasih. Lain halnya dengan seorang Dani yang menolak dan tidak mau mengorbankan jari-jarinya untuk dipotong. Mereka secara tidak langsung akan dihakimi oleh sanksi sosial dari masyarakat sekitarnya. Keberadaan mereka tidak akan diterima dan lambat laun akan dikucilkan oleh sesamanya sebab dinilai akan membawa banyak musibah dan bencana bagi kehidupan warga suku Dani yang lain.

Tradisi Niki Paleg sebagai simbol atas kehilangan dan dukacita perginya orang-orang terkasih menjadikan hal tersebut bukti bahwa kebudayaan merupakan keseluruhan yang mengandung pengetahuan, kepercayaan, adat istiadat, hukum, moral dan yang lainnya yang diperoleh sebagai bagian dari masyarakat. Untuk itu, makna dan pesan simbolik yang 
terkandung dalam tradisi Niki Paleg merupakan cara dari bagaimana orangorang suku Dani menginterpretasikan dunia mereka. Menurut teori interaksionisme simbolik Poloma (2004) oleh G. H. Mead dan Herbert Blumer bahwa interaksi simbolik mengarah pada karakter khas dan unik dalam hubungan antar manusia (h. 257). Hal unik tersebut terwujud dalam bentuk bahwa manusia menginterpretasikan setiap perbuatannya tidak sama dengan manusia lainnya. Begitupula dengan masyarakat Dani yang mengartikan sebuha peristiwa menyedihkan layaknya kematian melalui sebuah simbol yang menampakkan bentuk perbuatan. Simbol tersebut dijadikan sebagai isyarat atas rasa dukacita dalam

\section{METODE}

Dalam melakukan penelitian ini, telah dilakukan penyusunan yang sistematis untuk memudahkan hasil yang ingin dicapai.Begitu pula yang dilakukan penulis dalam penelitian ini.Karena jenis penelitian yang digunakan adalah penelitian kualitatif, maka langkah pertama yang dilakukan adalah dengan melakukan studi literatur

\section{HASIL DAN PEMBAHASAN}

Tradisi Niki Paleg dianggap bertujuan agar ruh tetap berada di dalam honai atau berkomunikasi sehingga tidak perlu diutarakan dengan menggunakan kata-kata.

Tradisi ini merupakan sebuah kenyataan yang berada di bumi Indonesia, khususnya tanah Papua. Budaya ini begitu dikenal sebagai suatu tragedi dimana seseorang merelakan satu atau bahkan keempat jarinya dipotong sebagai perwujudan rasa cinta kepada orang yang sudah meninggal. Namun, hal itu pula yang membuat penulis tertarik untuk bertujuan mengetahui dan membahas lebih jauh mengenai makna tradisi Niki Paleg oleh suku Dani. Penulis juga berharap tulisan ini nantinya dapat memberikan manfaat bagi para pembacanya.

pada buku-buku yang membahas tentang Tradisi Suku Dani, jurnal, dan penelitian yang telah dilakukan sebelumnya yang berkaitan dengan topik yang akan diangkat dalam penelitian ini.Data-data yang nantinya akan dikumpulkan berupa hasil kutipan dari sumber data yang berada di kajian pustaka.

rumah adat suku Dani hingga luka pada jari yang dipotong sembuh. Pemotongan 
berlaku pada semua jari kecuali ibu jari. Biasanya, bagian yang akan dipotong adalah dua ruas jari. Tradisi ini sudah dilakukan sejak zaman nenek moyang dan dilakukan secara turun-temurun, walaupun dalam pandangan medis hal tersebut adalah ekstrim.

Ritual pemotongan jari kebanyakan ditujukan kepada kaum ibu. Namun, anggota keluarga lain yang berasal dari pihak ayah ataupun ibu dapat juga menjadi subjek ritual ini. Makna lain dibalik ritual ini dapat diartikan sebagai usaha untuk menghindari bencana dan musibah yang dianggap telah menjadi faktor kerabatnya meninggal agar tidak kembali lagi menimpa yang lainnya. Terdapat berbagai macam cara untuk melakukan ritual pemotongan ini. Pemotongan dapat dilakukan dengan menggunakan benda-benda tajam seperti pisau, parang dan kapak. Usaha lainnya dapat dengan mengikat jari menggunakan sebuah tali hingga jari menjadi mati rasa kemudian dipotong.

Menurut Neale (1985) mengenai dukacita sebagai sebuah rasa kehilangan dan sebuah metode peralihan dari keadaan yang mengejutkan dan ketidakbisaan menyingkirkan keadaan di masa lampau menuju ke suasana menyedihkan, dan menggunakan nilai yang terdapat didalamnya sebagai fondasi format jalinan baru yang bermanfaat (h. 469-470). Hal tersebut tergambarkan oleh masyarakat suku Dani yang menilai proses dukacita sebagai proses dalam mengalihkan perasaan tercengang akibat tertampar oeh realita ditinggal orang terkasih selaku proses adaptasi dari kesedihan hingga mencapai keharmonisan yang baru.

Seorang Dani merelakan jarijarinya dipotong dikarenakan rasa dukacita yang timbul dari emosi jiwa yang melekat selama hidup. Emosi dan perasaan yang terbentuk selama hidup menjadikan mereka mampu menyakiti diri mereka sendiri secara fisik.

Tangan merupakan bagian dari raga manusia yang memiliki fungsi sangat utama mengarungi kehidupan. Manakala keadaan jari tangan sudah tidak lagi lengkap maka dapat diartikan pula bahwa kehidupan yang tengah dijalani tidak lagi sama. Melakukan kegiatan dengan jari yang tidak lagi lengkap pun akan menjadi kesulitan tersendiri. Kesulitan yang dimaksud pun adalah rasa sedih yang mendalam. Bagian jari yang telah dipenggal nantinya akan dikeringkan dan dibakar.

Peristiwa dukacita oleh suku Dani ini merupakan tradisi yang dinilai memiliki corak khas tersendiri. Dimana ritual Niki Paleg ini bersifat sangat pribadi, ekstrinsik dan berhubungan dengan konteks. Per 
anggota menyimpan pengetahuan tersendiri mengenai pengalamannya menghadapi kematian sehingga masing-masing anggota dapat menentukan pandangan yang tak biasa mengenai ditinggal orang-orang terkasih.

$$
\text { Layaknya yang dikutip dari }
$$
Wiryasaputra (2003), bahwa manusia mengalami dukacita, namun dengan tingkat dukacita yang berbeda-beda (h.69). Begitupula dengan masyarakat suku Dani, mereka pun melewati masa duka yang intens. Namun, tentu dengan jenjang yang berbeda-beda. Apabila terdapat aturan yang tidak mengizinkan kaum adam untuk menumpahkan tangisnya ketika berduka, maka tidak dengan masyarakat suku Dani. Setiap golongan tanpa terkecuali samasama meratapi kepergian orang-orang terkasih yang mati sehebat-hebatnya pada saat hari kematian dan masa berduka.

Dalam keadaan berduka yang dijalani oleh suku Dani, stress merupakan perwujudan atas kepergian yang dihadapi. Hal tersebut pun nampak dalam indikasi secara fisik.

Masyarakat suku Dani enggan untuk menjalani hidup seperti sebagaimana harusnya selama masa berduka. Sebab menurut mereka, kehilangan yang mereka rasakan tak selayaknya terjadi dalam kehidupan khususnya bagi kaum pria karena sangat mengagungkan nilai hubungan. Realita ditinggal mati oleh orang-orang terkasih membuat mereka menolak menerima kebenaran yang ada. Melalui tradisi Niki Paleg mereka seolah tak dapat pergi dari kesedihan mendalam yang berlarut-larut dengan terus memperingati kenangan bersama orang yang telah meninggal. Tak hanya secara fisik, peristiwa duka juga pun turut memengaruhi keadaan batin mereka selama hidup. Semakin dalam tekanan batin yang dialami maka semakin banyak pula jari yang akan dipotong.

Selain tradisi Niki Paleg, masyarakat suku Dani kerap melakukan perilaku tidak biasa seperti melemparkan tubuhnya ke kali Wamena sebagai rasa sesal mereka atas kepergian abadi anggota keluarga sebab keberadaan mereka masih sangat dibutuhkan di dunia. Perbuatan tersebut mengandung makna bahwa tubuh yang dilempar ke kali akan pergi bersama dengan kematian yang terjadi karena mereka tak bisa hidup tanpanya. Oleh sebab itu, ketidakmampuan melepaskan kematian orang-orang terkasih mereka bersedia untuk menjalani tradisi Niki Paleg dengan penuh penjiwaan terhadap nilai adat yang dipercayai. Tabiat yang melekat dalam tradisi ini bertujuan untuk memelihara 
kepaduan ikatan kasih dan sayang antara mereka yang bernyawa dan tidak.

Intensitas dukacita tidak didasari oleh ukuran makna subjek yang tak lagi ada, tetapi juga oleh kadar ikatan jalinan secara emosional antar subjek yang ditinggal dan meninggalkan. Perasaan dukacita yang dimiliki oleh suku Dani tidak hanya ditimbulkan oleh ikatan yang erat antar orangtua dan keturunannya, melainkan masyarakat suku Dani dan suku lainnya. Yang dimaksud adalah kerabat yang sudah tinggal bersama dalam jangka waktu yang tidak sebentar. Kerabat tersebut pun dapat merupakan suku diluar suku Dani namun memiliki peduli terhadap sesama. Bagi orang Dani, jika kerabat tersebut meninggal maka akan dianggap seperti bagian dari keluarga kandung sehingga jarijari mereka tetap harus dipotong. Sehingga ritual Niki Paleg pun akan tetap terlaksana di tempat yang berbeda dan dengan subjek yang tidak sama pula.

Para orangtua seperti ibu dan ayah yang sudah tak lagi memiliki anak atau orang yang dicintai pun tak mampu mengendalikan perasaan mereka jika tidak menunaikan ritual Niki Paleg. Dengan memotong jari-jari mereka akan dianggap bahwa mereka telah merelakan kepergian kerabat mereka yang telah meninggal secara resmi. Dan apabila mereka tidak turut menanggung pilu ketika jari mereka dipotong maka pilu akibat ditinggalkan akan semakin nyata. Masyarakat suku Dani yang tidak sanggup menahan perasaan mereka atas rasa sedih yang mendalam dan amarah atas rasa kehilangan dapat menghadapi pergantian pola berpikir bahkan perbuatan. Terlebih kesehatan mental yang terganggu sehingga muncul niatan-niatan untuk mengakhiri nyawa sendiri. Dilakukannya perbuatan tersebut dimaknai jika mereka melakukan hal demikian maka mereka akan pergi bersama anak atau kerabat yang telah meninggal.

Merupakan sebuah keharusan bagi masyarakat suku Dani agar segala hal dalam hidupnya diatur dalam norma adat. Imbas dari ritual Niki Paleg adalah bagian keluarga utama seperti paman dan bibi dari pihak ayah maupun ibu yang tengah berada dalam peristiwa dukacita akan diberikan tanggungan adat. Keharusan tersebut berupa pemberian harta berupa uang atau binatang peliharaan bernilai seperti babi kepada anggota kerabat terdekat seperti ibu atau ayah. Namun, apabila pihak keluarga belum dapat membayarnya, hal tersebut akan dinilai sebagai tunggakan adat. Namun, apabila sudah dapat dilunaskan maka pemimpin suku besar masyarakat suku Dani akan menggelar perjamuan secara besar-besaran untuk meramaikan 
peringatan akan kematian anggota keluarga. Dapat ditarik sebuah garis besar adanya tunggakan adat pun memiliki nilai yang bermakna sebagai sebuah norma adat dan memberikan imbas positif dalam bidang sosial-ekonomi masyarakat suku Dani.

Berbagai macam sumber mengatakan jika tradisi Niki Paleg ini sudah nyaris tidak

\section{PENUTUP}

Tradisi Niki Paleg dianggap bertujuan agar ruh tetap berada di dalam honai atau rumah adat suku Dani hingga luka pada jari yang dipotong sembuh. Dalam pelaksanaan tradisi ini bagian yang akan dipotong adalah dua ruas jari

Makna lain dibalik ritual ini dapat diartikan sebagai usaha untuk menghindari bencana dan musibah agar tidak terulang lagi. Pemotongan dapat dilakukan dengan menggunakan benda-benda tajam seperti pisau, parang dan kapak. Usaha lainnya dapat dengan mengikat jari menggunakan sebuah tali hingga jari menjadi mati rasa kemudian dipotong.

Masyarakat suku Dani enggan untuk menjalani hidup seperti sebagaimana harusnya selama masa berduka.Menurut mereka, kehilangan yang mereka rasakan tak selayaknya terjadi dalam kehidupan. berlaku lagi. Kini, sudah jarang masyarakat yang belakangan ini melangsungkan ritual ini. Salah satu akibatnya adalah masuknya pengaruh keagamaan yang berkembang disekitar daerah pegunungan tengah Papua. Namun, pria dan wanita lanjut usia dengan jari-jari yang sudah tak utuh sebagai dampak dari ritual Niki Paleg masih dapat ditemui.

Masyarakat suku Dani juga melemparkan tubuhnya ke kali Wamena sebagai rasa sesal mereka atas kepergian abadi anggota keluarganya. Perbuatan tersebut mengandung makna bahwa tubuh yang dilempar ke kali akan pergi bersama dengan kematian yang terjadi karena mereka tak bisa hidup tanpanya. Perasaan dukacita yang dimiliki oleh suku Dani tidak hanya ditimbulkan oleh ikatan yang erat antar orangtua dan keturunannya, melainkan masyarakat suku Dani dan suku lainnya.Karena bagi merekakerabat yang sudah tinggal bersama dalam jangka waktu yang tidak sebentar sudah mereka anggap sebagai keluarga.

Imbas dari ritual Niki Paleg adalah bagian keluarga utama seperti paman dan bibi dari pihak ayah maupun ibu yang tengah berada dalam peristiwa dukacita akan diberikan tanggungan adat. 


\section{DAFTAR PUSTAKA}

Wanulu, R. (2016). Makna Interaksi Simbolik Pada Proses Upacara adat Cumpe Dan Sampua Suku Buton Di Samarinda. Jurnal Ilmu Komunikasi. 4(3): 265-279

Haris, A. 2018. Makna Dan Simbol Dalam Proses Interaksi Sosial (Sebuah Tinjauan Komunikasi). Jurnal Risalah. Vol 29. 16-19

Rahmawati R. 2017. Makna Simbolik Tradisi Rebo Kasan. Jurnal Penelitian Komunikasi. Vol 20. 61-74
Agustianto, A. 2011. Makna Simbol Dalam Kebudayaan Manusia. Jurnal Ilmu Budaya, Vol 8. 1-8

Wardani, T. 2017. Upacara Adat Mantu Kucing Di Desa Purworejo Kabupaten Pacitan (Makna Simbolis Dan Potensinya Sebagai Sumber Pembelajaran Sejarah). Jurnal Agastya. Vol 7. 1

http://repository.uksw.edu/bitstream/12345 6789/8510/1/T2_832009008_BAB\% 20I.pdf (Diakses pada tanggal 13 Juni 2019)

https://id.wikipedia.org/wiki/Suku_Dani (Diakses pada tanggal 13 Juni 2019) 